\title{
MŁODZIEŃCZE EKSPERYMENTY Józefa KorzeniowsKiego Z FORMĄ DRAMATYCZNĄ
}

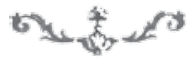

J

ÓzEF KoRzENIOWSKI, metrykalnie najbliższy pierwszej generacji romantycznej (starszy o rok od Adama Mickiewicza) i najczęściej przez jej pryzmat oceniany bodajże od chwili debiutu, uchował się w historii literatury głównie dzięki swym późnym powieściom, które wraz z obrazkami obyczajowymi Józefa Ignacego Kraszewskiego, Józefa Dzierzkowskiego czy Zygmunta Kaczkowskiego współorganizowały poetykę protorealizmu ${ }^{1}$, zwaną przez mniej wyrozumiałych komentatorów poetyką powieści biedermeierowskiej czy nawet tendencyjnej, a przez współczesnych pisarzowi krytyków postrzeganą po prostu w kategoriach dochodowej chałtury². Słynne oskarżenie Korzeniowskiego o zdradę narodową ze względu na sposób przedstawienia realiów życia pod zaborami na kartach Krewnych Julian Klaczko poprzedził gorzkim wyrzutem z powodu opuszczenia przez pisarza wyżyn dramatu dla przyziemnych rejonów powieści (romantyczny krytyk nazwał to zejściem „ze sfery natchnienia i ideału do wątpliwego posłannictwa bawienia mas" ${ }^{3}$ ).

Dramatyczna bowiem twórczość autora Krewnych, dzisiaj właściwie zapomniana ${ }^{4}$, traktowana była w swoim czasie bardzo poważnie. Nasuwa się wręcz

1 Zob. J. Bachórz, Realizm bez „chmurnej jazdy”. Studia o powieściach Józefa Korzeniowskiego, Warszawa 1979.

2 Takie stanowisko przyjął m.in. Karol Estreicher (Szkice bibliograficzne z dramaturgii polskiej, „Dziennik Literacki” 1853, nr 30).

3 J. Klaczko, [„Krewni” Korzeniowskiego], „Wiadomości Polskie” 1857; cyt. za: Polska krytyka literacka (1800-1918). Materiaty, t. 2, red. Z. Szmydtowa, Warszawa 1959, s. 347.

4 Gdyby „zapomnianość” mogła być cechą, a jeszcze lepiej cechą stopniowalną, to trzeba by było przyznać, że dramaty Korzeniowskiego są jednak „bardziej zapomniane” 
przypuszczenie, że przez czytelników i widzów, przez dyrektorów teatrów i teatralnych krytyków dramaturg Korzeniowski był odbierany poważniej, niż sam siebie odbierał. Znane świadectwa dystansu do własnej osoby i twórczości są jednak późniejsze niż jego pierwsze prace dramatyczne, choć czasem tych właśnie prac dotyczą. Spóźnienie owego autokomentarza, które jednocześnie tłumaczy lekceważący stosunek do młodzieńczych prób większą pisarską dojrzałością, samo znajduje wytłumaczenie w fakcie, że dyskusje wokół tych wczesnych utworów rozgorzały w momencie wysforowania się Korzeniowskiego na pierwsze miejsce w dramaturgii krajowej - przynajmniej w opinii współczesnych.

Szczyt popularności (albo i tylko początek jej szczytowej fazy) przypadł na lata czterdzieste, a więc nie był rezultatem jakiegoś rozpaczliwego wysiłku promowania czegokolwiek $\mathrm{w}$ artystycznej pustyni pierwszych lat polistopadowych, gdy w sytuacji przetrzebienia kulturalnych elit można by się spodziewać wypatrywania przysłowiowych raków na bezrybiu. Owszem, kilka lat wcześniej zamilkł Aleksander Fredro, ale jednak sukcesowi Korzeniowskiego towarzyszyły już debiuty dorastających pisarzy drugiego pokolenia romantyków, w tym debiut Cypriana Norwida. Uznany dramaturg miał wtedy za sobą dwudziestoletnią, żmudną a wytrwałą praktykę, znaczoną co jakiś czas książkowym wydaniem lub inscenizacją, toteż już na początku lat czterdziestych zaczęły się ukazywać syntetyzujące opracowania jego twórczości5.

Nie był stabilny w tych pierwszych syntezach zestaw omawianych utworów ${ }^{6}$, a wprowadzane w nim zmiany najwyraźniej nie wynikały jedynie z iloś-

od jego powieści, wydawanych jeszcze po drugiej wojnie światowej, także w serii „Biblioteki Narodowej” (J. Korzeniowski, Krewni. Powieść, oprac. S. Kawyn, Wrocław 1955; tenże, Kollokacja, oprac. i wstęp Stefan Kawyn, Wrocław 1958).

5 Rozprawiano w nich o dojrzewaniu Korzeniowskiego do opanowania formy dramatycznej, do wiązania konfliktu i prowadzenia akcji, ewentualnie do różnicującego charakteryzowania postaci; niewiele pisano o stylu, a bodaj wcale o wierszu - ten aspekt uwzględnił na serio dopiero Piotr Chmielowski (Józef Korzeniowski. Jego życie i działalność literacka. Zarys biograficzny, Petersburg 1898), przynajmniej w tym sensie, że wprowadził go jako stały element opisu kolejnych etapów biografii artystycznej Korzeniowskiego.

6 W recenzjach poszczególnych tomów o wyborze przesądzała oczywiście ich zawartość - i dlatego Aleksander Tyszyński w 1841 roku omówił trzy Dramata zebrane w tomie wydanym dwa lata wcześniej: Klarę, Anielę i Piękną kobietę (A. Tysz[yński], Kronika literacka. Dramata J. Korzeniowskiego tom I, „Biblioteka Warszawska” 1841, t. 1, s. 637-646), z których dwa pierwsze, ogłoszone pierwotnie jako Próby dramatyczne, zrecenzował anonimowo w "Gazecie Polskiej” Stefan Witwicki ([S. Witwicki], Rozbiór książki majacej tytut: „Próby dramatyczne przez Józefa Korzeniowskiego”..., „Gazeta Polska” 1829, nr 70-72). Przygotowanie w tych recenzjach podstawy dla przyszłych opracowań „zbiorczych” polegało na porównawczym przywołaniu kontekstu literackiego przez Witwickiego, a w pracy Tyszyńskiego na zarysowaniu perspektywy już histo- 
ciowego przyrostu dorobku pisarza. Nie tylko zresztą w perspektywie odbiorczej płody pierwszego okresu twórczości Korzeniowskiego - obejmującego lata pobytu pisarza w Warszawie (1819-1823) i pracy w Liceum Krzemienieckim (1823-1833) - miały nierówny status. $\mathrm{O}$ wykluczeniach przesądziły jednak najpierw decyzje autorskie, następnie prawa rynku wydawniczego, a dopiero na końcu opinie recenzentów. Dwa dramaty - Pelopidowie (powst. 1826, wyst. 1830) i Bitwa nad Mozgawa (powst. 1827) - z woli autora trafiły do szuflady i wskutek zaskakującej lojalności przyszłych edytorów spoczywają w niej do dzisiaj. Dymitr i Maria (pierwotnie Wróżba i zemsta, powst. 1827-1828, wyst. 1831) w całości ukazał się dopiero w 1846 roku i wtedy też doczekał się krytycznego omówienia. Trudniej natomiast wyjaśnić słabsze notowania Mnicha (powst. 1824 lub 18267, wyd. 1830) czy wydanej w 1839 roku Pięknej kobiety (powst. 1829, wyst. 1834) - trudniej tym bardziej, że stale zajmowały wysoką pozycję wśród krytyków pierwsze „próby dramatyczne”, opublikowane w 1826 roku - Klara (1820) i Aniela (1823/1825).

rycznoliterackiej. W historycznej syntezie dramatu polskiego z 1843 roku Kazimierz Władysław Wójcicki wymienił z prac Korzeniowskiego jedynie Karpackich górali (K.W. Wójcicki, Spojrzenie na literaturę dramatyczną polską, „Biblioteka Warszawska” 1843, t. 2, s. 293-323). Dla Aleksandra Przezdzieckiego Korzeniowski pozostawał w 1844 roku autorem Klary, Anieli, Mnicha, Pięknej kobiety, Umarłych i żywych, Karpackich górali oraz Żydów - dramatów potraktowanych przezeń, z pewnymi wyjątkami, dość okrutnie za pomocą skojarzeń i porównań inaczej niż u Witwickiego ustawionych, bo na innych aspektach skoncentrowanych (A. Przezdziecki, O dzisiejszym stanie sztuki dramatycznej $w$ Polsce ze względu na najnowsze $w$ tym rodzaju utwory, „Biblioteka Warszawska” 1844, t. 2, s. 109-133). Oponent Przezdzieckiego, zainicjowawszy pamiętną dyskusję o „węźle dramatycznym”, argumentował sprytnie, odwołując się do innego materiału, i na pierwszy plan wysunął nowsze prace dramaturga - Fabrykanta i Pannę mężatkę (Kl. [K. Witte], „Fabrykant” w dwóch, „Panna mężatka” w trzech aktach, komedie oryginalne proza napisane przez Józefa Korzeniowskiego, „Biblioteka Warszawska" 1844, t. 3, s. 427-440). Jan Szlachtowski, autor Komedii polskiej w wieku XIX, ogłoszonej anonimowo w 1850 roku, porównał z komediami Fredry Fabrykanta, a przede wszystkim Żydów ([J. Szlachtowski], Komedia polska w wieku XIX, „Pamiętnik Literacki” 1850, nr 13, s. 289-332). W 1853 roku Karol Estreicher podjął myśl Przezdzieckiego, rozszerzając zestaw porównawczo oglądanych dramatów o Pannę mę$\dot{z} a t k e ̨$ i Starego męża (Oe [K. Estreicher], Szkice bibliograficzne z dramaturgii polskiej, „Dziennik Literacki” 1853, nr 30, s. 235).

7 Utrwaloną w bibliografiach i podręcznikach datę 1824 podważa autorskie sprostowanie w liście do Estreichera $\mathrm{z} 1858$ roku, w którym Korzeniowski wskazuje na rok 1826 - zob. K. Kossakowska-Jarosz, Wokót „Mnicha” Józefa Korzeniowskiego (kilka uściśleń i sprostowań), „Zeszyty Naukowe WSP w Opolu. Filologia Polska” 1994, s. 95-104. 
Utarła się przy tym tradycja uznawania Klary za warsztatową przymiarkę do suwerennie postrzeganej Anieli ${ }^{8}$. Dopiero Piotr Chmielowski jakoś ten porównawczy schemat przewartościował. Dostrzegłszy bowiem między obiema „próbami” podobieństwo w konstrukcji postaci i zawiązaniu konfliktu, wykazał niewystarczalność fabularnej materii dla pięcioaktowej tragedii. Konfliktowe napięcia w relacjach między bohaterami mogły - zdaniem krytyka - wypełnić co najwyżej jednoaktówkę, Klarę, nazwaną „dramacikiem” i skojarzoną z mniejszymi formami poetyckimi, wcześniej już przez jej autora opanowanymi ${ }^{9}$. Przewartościowanie polegało więc na tym, że Chmielowski dostrzegł w Klarze lepsze niż w Anieli dopasowanie formy dramatycznej do młodzieńczych predyspozycji twórczych Korzeniowskiego.

Współcześni poecie krytycy mniej lub bardziej zdecydowanie odmawiali tej formie prawa przynależności do rodzaju dramatycznego. Bez niespodzianek - najłatwiej wydawali takie wyroki teoretycy klasycyzujący. Wprawdzie reguły dawnego klasycyzmu francuskiego - trzech jedności, stosowności i dobrego smaku - zastępował już w tym czasie dogmat o konstruowaniu akcji na „węźle dramatycznym”, ale klasycyzm tkwił tutaj w samej podstawie filozofii gatunku, opartej na ahistorycznym oglądzie zjawisk przez pryzmat jakiejś niezmiennej zasady.

Taką postawę przyjął Aleksander Przezdziecki. Po doświadczeniach romantyzmu jego wystąpienie mogłoby się wydawać krokiem wstecz, aczkolwiek kategoria akcji, z czasem coraz wyraźniej formowanej w kształt Freytagowskiej piramidy ${ }^{10}$, zyskała $w$ teorii dramatu drugiej połowy XIX wieku status ponad-

8 Witwicki poświęcił pierwszej „próbie dramatycznej” zaledwie jeden akapit. Później dysproporcja nie była aż tak rażąca, ale niekoniecznie jej zmniejszaniu przyświecał zamiar dowartościowania Klary. Przezdziecki na przykład poświęcił jej więcej uwagi tylko po to, by obszerniej dowodzić tez dyskredytujących ów dramat. Zebrane przezeń argumenty nie musiały przy tym wcale służyć tak złej sprawie i to właśnie zdawał się nawet wcześniej sugerować Tyszyński, zresztą bez intencji wypromowania jednego dramatu kosztem drugiego.

9 Chmielowski (dz. cyt., s. 29) nazwał Klarę „oddźwiękiem” Ernestyny i Światełka, utworów reprezentujących w młodzieńczej twórczości Korzeniowskiego nurt sentymentalnych dum i ballad, odróżniany od „poważnych” i „uroczystych” listów poetyckich oraz ód.

10 Gustaw Freytag (1816-1895) był twórcą teorii piramidalnego rozwoju akcji dramatycznej poprzez ekspozycję, „moment pobudzający” i „wzrost czynności” aż do punktu kulminacyjnego, przypadającego na połowę trzeciego aktu, a następnie „moment tragiczny” inicjujący „spadek czynności” prosto ku końcowej katastrofie. W swoim czasie teoria Freytaga, dobitnie i wyczerpująco wyłożona w rozprawie Die Technik 
czasowego wyróżnika gatunkowego.

Aleksander Tyszyński natomiast spojrzał historycznie. I to jak! Najpierw obwołał Korzeniowskiego pierwszym w polskiej dramaturgii nowatorem, który już w debiutanckich utworach „[...] w treści, w układzie odrzucił więzy władnącej w tym czasie szkoły, długie frazy rozumu zastąpił językiem uczuć, dowcip poezją; w wykładzie, w miejscu aleksandrynów, na wzór tragików Włoch, Niemiec i Anglii, wiersz bezrymowy (pięciostopowy) jako dialogowi właściwszy przyjął" ${ }^{\prime \prime}$. Tego byłoby jednak za mało na w pełni świadomy projekt nowej literatury - a z perspektywy 1841 roku, w którym Tyszyński komentował wznowienie wydania „prób dramatycznych”, połowiczność rozwiązania opartego na samych tylko środkach technicznych objawiałaby się w całej swej rażącej niewystarczalności. Należało więc - przy tak życzliwej autorowi postawie, jaką prezentował recenzent - wykazać, że Korzeniowski stworzył nowy, oryginalny projekt dramatu, który oczywiście nie spodobał się w okresie nazwanym wiekiem „ścisłych reguł”, ale też nie doczekał się kontynuacji w dwóch następnych okresach, rozwijających - zdaniem Tyszyńskiego - inne niż zaproponowany przez Korzeniowskiego warianty estetyk nieklasycznych. Stąd wynika, że między okresem klasycyzmu, obejmującym w periodyzacji Tyszyńskiego jeszcze pierwszą połowę lat dwudziestych (skoro pierwsze „próby" Korzeniowskiego, wydane w 1826 roku, miały powstać jeszcze w tym okresie), a czasem pisania recenzji (1841) upłynęły już dwie epoki, a przynajmniej jedna upłynęła, zaś druga zdążyła już zaznaczyć swoją odrębność. Pierwszą krytyk nazwał okresem „historyczności”, drugą - „fantastyczności”.

Cokolwiek by mówić o wartości ich definiowania pojęć stosowanych w nazwach, trzeba docenić zdolność sklasyfikowania różnych typów literatury romantycznej oraz wyznaczenia cezury wewnętrznej w przedziale czasowym obejmującym nie całą nawet epokę, a zaledwie okres twórczej aktywności pierwszego romantycznego pokolenia. „Historyczność”, odmienianą w pracach romantycznych teoretyków dramatu przez wszystkie przypadki, Tyszyński objaśnił przez odwołanie do rozpraw Seweryna Goszczyńskiego i Dominika Magnuszewskiego, odrzucając stanowisko sprowadzające tę kategorię do historycznego weryzmu. Nie sprecyzował natomiast znaczenia „historyczności” jako jednostki periodyzacyjnej. Podobnie jak w przypadku „fantastyczności”, w której zmieściły się: „alegoria, świat duchów, mistycyzm, uosabianie pojęć

des Dramas - ogłoszonej w 1863 roku, wielokrotnie wznawianej i tłumaczonej, a przez Wilhelma Diltheya uznanej nawet za współczesny odpowiednik Poetyki Arystotelesa - wydawała się epokowym odkryciem i stała się najsłynniejszym wykładem zasad budowy akcji.

11 A. Tysz[yński], dz. cyt., s. 637. 
i wyobrażeń, uzmysławianie ludzi i rzeczy, wszelkie słowem fantastyczności barwy, wszelkie metafizyczne rysy"12. Alternatywę, jaką wobec obu tych poetyk przedstawiały dramaty Korzeniowskiego, stanowił - według Tyszyńskiego - „obraz uczuć niezmiennych, z ludzkości ogółu wziętych, wszystkim czasom i miejscom własnych, poezji barwą odzianych"13. Różnicę krytyk przedstawił właśnie na przykładzie pierwszej „próby dramatycznej”, a dokładnie na występie monologującej bohaterki tytułowej:

Klara pozostająca sama, zajmująca jest dla nas w swych myślach. Tu p o e t a - h i s to ryk w każdy wiersz myśli włożyłby wyrażenie miejscowe, wyraz prowincjonalny, przysłowie; p o et a - fa n t a st y k raczej by ukazał tu ducha, ducha z słowem tajemnym i ręką z płomienia. [...] Klara w obrazie autora mówi jak postać ziemska, wprawdzie $\mathrm{z}$ barwą poezji, ale z czuciem i słowem po wszystkie czasy i od każdego pojętym. ${ }^{14}$

Wcześniej Tyszyński zaznaczył, że w tym krótkim dramacie postać tytułowa „jest sama prawie treścią"15 - i dlatego zapewne spośród wydanych w recenzowanym tomie trzech wczesnych dramatów Klarę postrzegał jako „najpoetyczniejszą"16.

Z tych kilku twierdzeń wyłania się jasno kierunek analizy Tyszyńskiego. Krytyk najwyraźniej zmierzał w stronę wpisania Klary (najchętniej razem z całą resztą wczesnych dramatów Korzeniowskiego) w tradycję sceny lirycznej, gatunku uformowanego w drodze laboratoryjnego eksperymentu w pracowni Jeana-Jacques'a Rousseau, a charakteryzującego się wyeksponowaniem na pierwszym planie tragicznych zmagań głównej - i najczęściej jedynej - postaci z własnymi myślami w stanie krańcowego spiętrzenia namiętności, które w chwilach największego natężenia przekracza już próg ekspresji słownej, sięgając do pozawerbalnych środków wyrazu, to jest gry ruchowej i muzyki instrumentalnej ${ }^{17}$. Z ostatniego elementu polscy autorzy scen lirycznych (Jan Czeczot, Adam Mickiewicz ${ }^{18}$ ) często rezygnowali, zachowując jednak dynamikę wewnętrznej walki bohatera, która musiała wszak zastąpić nieobecną w tej formie akcję „zewnętrzną”. Tego Klarze Korzeniowskiego brakuje, a więc mimo zewnętrznej szczątkowości akcji sceną liryczną nazwać jej nie można, co jed-

12 Tamże, s. 638.

13 Tamże.

14 Tamże, s. 638-639.

15 Tamże, s. 638.

16 Tamże.

17 Zob. Z. Wołoszyńska, Scena liryczna, w: Słownik literatury polskiego oświecenia, pod red. T. Kostkiewiczowej, Wrocław 1996, s. 560-566.

18 Zob. M. Witkowski, Na drodze ku „Dziadom”, w: Świat teatralny młodego Mickiewicza, Poznań 2006, 139-167. 
nak nie przesądza, by nie mogła być lirycznym dramatem. I w tym może tkwiła istota owej „poetyczności”.

Jednak stopniowalność tej cechy i zarejestrowane przez krytyka mniejsze jej natężenie w późniejszych dramatach zdają się sugerować, że dramaturgia Korzeniowskiego ewoluowała ku rezygnacji z owych najwyrazistszych znamion swojej poetyki.

Jakoż i rozbudowa zewnętrznej akcji w drugim z kolei dramacie, Anieli, mogła istotnie naprowadzić Stefana Witwickiego na przypuszczenie, że Klara - wprost nazwana przezeń „przydłuższą sceną liryczną” - „[...] jest to utwór, do którego zapewne i sam autor mniejszą wartość przywiązuje”19. A jeszcze wydawał się on recenzentowi wtórny, wzorowany jakoby na dramie Augusta Kotzebuego Syn nieprawy, wystawianej w Warszawie i Lwowie od lat dziewięćdziesiątych XVIII wieku także pod tytułem Dziecko miłości, ale drukiem ogłoszonej w polskim przekładzie Stanisława Platera dopiero w 1826 roku, a więc - przypomnijmy - w roku pierwszego wydania Prób dramatycznych Korzeniowskiego ${ }^{20}$. Porównanie obu tekstów ${ }^{21}$ odsłania różnice $w$ położeniu bohaterów, w budowie akcji, w stylu, formule gatunkowej i regułach świata przedstawionego. Syn nieprawy Kotzebuego ewoluuje od zabawnej komedii intrygi, zarysowanej w pierwszych scenach, w stronę poważnej dramy rodzinnej. Klara tymczasem jest nastrojowo jednolita. Niektórzy twierdzili, że aż nadto. Odnajdywano tę cechę zresztą nie tylko w Klarze, i nie tylko na poziomie porządku świata przedstawionego, który określa kondycję bohaterów i możliwe rodzaje konfliktów. Chmielowski z analizy wiersza wywodził jako właściwość stylu wszystkich warszawsko-krzemienieckich dramatów Korzeniowskiego brak dbałości o językowe zindywidualizowanie postaci. Źródłem tej postawy pozytywistycznego badacza mogła być swoista absolutyzacja teatralnego realizmu, skłaniająca krytyków do postrzegania wiersza białego w kategoriach formy pośredniej, znamienia „przejścia od stylu tragedii francuskiej do dramatu mieszczańskiego"22.

Inna sprawa, że kierunkiem dalszego rozwoju swej twórczości Korzeniowski sam dał powody do formułowania takich sądów. Wszakże w latach dwudziestych, kiedy powstawały jego pierwsze „próby dramatyczne”, wrażliwość

19 [S. Witwicki], dz. cyt., nr 70, s. 305.

20 Zob. Dramat obcy w Polsce 1765-1965. Premiery. Druki, Egzemplarze, t. 1, Kraków 2001, s. 363. Fakt niedawnego ogłoszenia przez Platera Wyboru dzieł dramatycznych Augusta Kotzebue odnotował też w swej recenzji Witwicki.

21 Zob. M. Dybizbański, Melancholijny świat wczesnych dramatów Józefa Korzeniowskiego, w: Światy melancholii. W 50o-lecie „Melencolii” Albrechta Dürera (1514-2014), pod red. A. Mazur, M. Dybizbańskiego [w druku].

P. Chmielowski, dz. cyt., s. 27. 
odbiorców - już przyzwyczajona do prozy dram i melodramatów - tolerowała jeszcze konwencjonalną stylistyczną jednolitość tradycyjnej dramaturgii wierszowanej ${ }^{23}$. Ta jednak nie pociągała za sobą jednakowości temperamentów, zabójczej z punktu widzenia dynamiki akcji, której motorem pozostaje wszak w dramacie dialog. W tym aspekcie Chmielowski nie zgłaszał zastrzeżeń ani wobec Klary, ani wobec kolejnych wczesnych dramatów Korzeniowskiego. Przeciwnie, podkreślał, że „[...] już od najpierwszego dramaciku zapisanego w nowym kierunku, Korzeniowski wprowadził dialog istotnie dramatyczny", bo jakkolwiek „można mu zarzucić sztywność lub rozwlekłość, ale niepodobna odmówić własności posuwania akcji, choćby bardzo powolnego, naprzód”24.

Zdaniem Przezdzieckiego tę akurat zdolność osiągał dialog Klary dzięki prostej i niedramatycznej zasadzie spójności, polegającej na tym, że „[...] w każdej scenie zapowiada się, co będzie w następnej, ciekawość przeto pierwej zaspokojoną nim dostatecznie obudzoną bywa" ${ }^{25}$. Ponadto krytyk orzekł, że sprawność w konstruowaniu dialogów pisarz osiągnął dopiero w dramatach prozatorskich (a więc i powstałą w roku 1829 Piękną kobietę należałoby zaliczyć już do drugiego okresu jego twórczości), które jednak nadal pozbawione były „węzła dramatycznego”. Ten najbardziej pożądany czynnik pojawił się - zdaniem Przezdzieckiego - tylko w Anieli, lecz ta z kolei dzieliła z innymi wczesnymi dramatami Korzeniowskiego dialog „liryczny, elegijny, rozwlekły, a zatem nienaturalny" ${ }^{26}$.

Gdyby nie obawa, że mógł to być istotnie wynik pisarskiego niewyrobienia, można by zasugerować, iż Przezdziecki w zapiekłej niechęci niepotrzebnie podporządkował wnioski swych analiz jednostronnemu wartościowaniu, ponieważ intencją dramatopisarza nie było w tym przypadku ani pobudzanie ciekawości dla rozwoju wypadków, ani kopiowanie natury. Korzeniowski mógł jednak całkiem nieświadomie zaprojektować taki dramat, który ostentacyjnie rezygnując z fabularnych zawikłań i niespodzianek, zatrzyma uwagę czytelnika bądź widza na czymś innym niż przebieg akcji. Tym „czymś innym” mogły być znamiona liryczności albo raczej to, co one sobą wyrażały.

23 W klasycznej tragedii wszyscy bohaterowie stosują wszak retorykę najwyższej próby. Owszem, pochodzą z reguły ze środowisk kształconych w sztuce wymowy. Ale i komedia klasyczna indywidualizuje język postaci najczęściej tylko za pomocą charakterystycznych powiedzonek w rodzaju „mocium panie”. Dodać można, że i bohaterowie klasycznej epiki wierszowanej posługują się kunsztownym językiem narratora (zob. M. Głowiński, Dialog w powieści, w: tegoż, Gry powieściowe, Warszawa 1973, s. 41).

24 P. Chmielowski, dz. cyt., s. 28.

25 A. Przezdziecki, dz. cyt., s. 114.

26 Tamże, s. 112; podkr. - M.D. 
Liryczność, jako kategoria estetyczna wskazująca na podmiotowość wypowiedzi, $w$ dramacie romantycznym i w teoretycznej refleksji doby romantyzmu funkcjonowała - jak to przekonująco wykazała Agnieszka Ziołowicz w obszernym studium monograficznym tego tematu - jako forma ekspresji zarówno „ja" monologującego bohatera, jak i ,ja" autorskiego ${ }^{27}$. W tym drugim wariancie liryczność, polegająca na subiektywizacji rzeczywistości przedstawionej dramatu, utożsamiana bywała z gestem zaproszenia przez twórcę do świata własnej wyobraźni, najlepiej poprzez podkreślenie jego kreacyjnej zależności od autorskiego podmiotu. Tak więc liryczność, odnajdywana w tej postaci w Burzy i w Śnie nocy letniej Williama Shakespeare’a, a później w Balladynie i Lilli Wenedzie $e^{28}$ Juliusza Słowackiego, zaczęła w ówczesnej teorii jakoś niebezpiecznie dryfować w stronę ironii romantycznej.

Recenzenci dramatów Korzeniowskiego tych koneksji im jednak nie przypisywali. W Klarze najczęściej widzieli rozbudowaną scenę liryczną, a więc patrzyli na nią przez pryzmat monologów tytułowej bohaterki, obudowanych dodatkami w formie dialogów o nikłej kontrowersyjności, z trudem napędzających wątłą akcję. Paradoksalnie ci, którzy próbowali w ten sposób ratować wartość dramatu, właściwie go pogrążali. Przezdziecki odwrotnie - jawnie oskarżał, a niechcący bronił. Spojrzawszy bowiem całościowo na jego niedramatyczność (brak akcji, brak „charakterów”, brak nawet sytuacji prawdziwie konfliktowej), odnalazł spójność tekstu w jego liryczności. I nawet określił ją gatunkowo, orzekając, że „Klara jest elegią, a nie dramatem”29.

Spośród gatunków usankcjonowanych klasycystyczną teorią poezji elegia należy do form lirycznych najsilniej w wymowie stonowanych i najbardziej $\mathrm{w}$ treści osobistych. Stanowi zatem przeciwieństwo klasycznie, po arystotelesowsku pojmowanej dramatyczności.

W historycznym kontekście - nawet takim, jakim go zarysował w swej rozprawce Tyszyński - genologiczna kwalifikacja Przezdzieckiego rzeczywiście wyznacza Klarze miejsce osobne, odległe zarówno od poetyki „ścisłych reguł”, jak i od estetyki „historyczności” oraz „fantastyczności” - przy czym ta ostatnia, jak wynika $z$ opisu, określała w mniemaniu krytyka raczej formę epickiego dramatu historycznego (tyle że zamiast w realia lokalne wyposażonego w duchy) niż dramatu lirycznego na sposób znany ze scenicznych baśni Shakespeare’a. Liryzm pierwszych „prób dramatycznych” Korzeniowskiego, a zwłaszcza „najpoetyczniejszej” z nich Klary, byłby więc niebaśnio-

Zob. A. Ziołowicz, Dramat i romantyczne „ja”. Studium podmiotowości $w$ dramaturgii polskiej doby romantyzmu, Kraków 2002.

28 Zob. tamże, s. 47-49.

29 A. Przezdziecki, dz. cyt., s. 111. 
wym liryzmem prawdy wewnętrznego przeżycia, szczerości osobistych wynurzeń autorskiego „ja”. Przynajmniej według teoretycznych założeń gatunkowych elegii, „[...] która jest wyrazem żywego wzruszenia serca, i w której się uczucie przyjemne z nieprzyjemnym i żałosnym jednoczy”, zaś jej „materia i ton” wynikają „z rodzaju wzruszeń i namiętności, które napełniają r y mo t wó r c y d u s z ę"30. Skojarzenie wydaje się o tyle uzasadnione, że w Klarze istotnie pojedyncze głosy postaci - niczym różne strony jednej osobowości, upostaciowane w figurach kobiety, mężczyzny, dziecka i starca - zlewają się w jeden elegijny głos.

Podobne reakcje wywoływała jeszcze Aniela, budząca nawet w swoim czasie nadzieje romantyków. Mickiewicz dostrzegł w niej „próbę wcale dobrą i wielce obiecującą" ${ }^{11}$, a Słowacki jej wspomnienie opisał jako „sen jakiś smutny i miły" ${ }^{2}$. Trudno dziś przy Anieli obejść się bez tych dwóch cytatów - w oczywisty sposób dowartościowują przedmiot opisu i przydają dodatkowego sensu wysiłkowi współczesnego badacza. Jednak czuć się daje przy ich przywołaniu gorzki smak przypomnienia odnajdywanych po latach świadectw dla pośmiertnej rehabilitacji. Zdania wielkich poetów, wyrażone w prywatnej korespondencji, nie mogły ani oddziałać na opinię publiczną, ani samego Korzeniowskiego zainspirować ni utwierdzić w jego artystycznych wyborach. Inna sprawa, że Słowacki za życia wielkiego posłuchu nie miał, a opinia Mickiewicza nie była jednak całkiem pochlebna. Dokładnie brzmiała tak: „Korzeniowski z kilku sztuk zrobił swoją Anielę (czy też inną, nie pomnę, która z nich dłuższa, bo są dwie, Klara i Aniela, jedna głupia), próbę wcale dobrą i wiele obiecującą"33.

Mimo poczynionego zastrzeżenia nie ulega wątpliwości, że pochwała dotyczy Anieli, skoro „głupia” miała być sztuka krótsza, a więc Klara. Kategoryczność sądu tłumaczy uchwytna w liście do Antoniego Edwarda Odyńca nuta zniecierpliwienia uciążliwym obowiązkiem recenzowania płodu muzy adresata, uformowanego w kształt rycerskiej dramy, czyli wydanej w 1829 roku Izory. W ramach zbudowanego na tej recenzji wykładu utwór Korze-

30 Prawidła wymowy i poezji. Wyjęte z dzieł Euzebiusza Słowackiego, Wilno 1843, s. 243; podkr. - M.D.

31 A. Mickiewicz, List do Antoniego Edwarda Odyńca, Petersburg 28 kwietnia / 10 maja [1828], w: tegoż, Dzieła. Wydanie Rocznicowe, t. 14: Listy. Część pierwsza. 1815-1829, oprac. M. Dernałowicz, E. Jaworska, M. Zielińska, Warszawa 1998, s. 471.

32 J. Słowacki, List do matki, Genewa, 5 lutego 1835, w: Korespondencja Juliusza Słowackiego, oprac. E. Sawrymowicz, t. 1, Wrocław 1962, s. 283.

33 A. Mickiewicz, List do Antoniego Edwarda Odyńca, w: tegoż, Dzieła..., s. 471. 
niowskiego pełnił funkcję exemplum dla programu romantycznego dramatu historycznego opartego na wzorach czerpanych z twórczości Friedricha Schillera i Williama Shakespeare’a. Tym samym otworzył Mickiewicz tradycję - zrodzoną niezależnie od jego prywatnego spostrzeżenia i uznania zręczności dramaturga w pracy kompilacyjnej - czytania Anieli przez pryzmat pierwowzorów odnajdywanych w Intrydze i miłości Schillera dla konstrukcji postaci i rodzaju konfliktu, w Hamlecie zaś dla kreacji Gustawa Przeworskiego, niezdolnego dokonać wyboru między mezaliansowym zobowiązaniem wobec Anieli a klasowo poprawną miłością do Heleny. Ten aspekt, rozmaicie naświetlany, wydobywany był między innymi w recenzjach $\mathrm{Wi}$ twickiego, Przezdzieckiego, później zaś wrócił - z racji tematycznego ukierunkowania tych opracowań już historycznoliterackich - w pracach Mariana Szyjkowskiego ${ }^{34}$ i ostatnio Krzysztofa Kurka ${ }^{35}$.

Równolegle rozwijał się drugi nurt czy sposób czytania Anieli - i temu bliższy byłby komentarz Słowackiego (też sformułowany także przed wyraźnym zarysowaniem owego nurtu, i tak samo, jak ów sąd Mickiewicza, wyrażony prywatnie):

Co się dzieje z autorem Prób dramatycznych? Aniela jego często mi przychodzi na pamięć jak sen jakiś smutny i miły. Chciałbym bardzo wiedzieć, czy zawsze pracuje, czy może pracować i nad czym pracuje. Jest to jeden z tych ludzi, którym dotąd nie oddano słuszności. Potrzeba by mniej być skąpymi w pochwałach i w zachęcaniu. ${ }^{36}$

Zapis doznań wywołanych lekturą Anieli znów przypomina projekcję stylu odbioru elegii (odczucie smutku i przyjemności). Sposób lektury mniej analityczny, bardziej osobiście wrażeniowy, pozwalał uchwycić ów rys indywidualny dramaturgii Korzeniowskiego. Znamienny, choć nie w każdych okolicznościach dobrze odbierany.

Recenzent „Gazety Warszawskiej” zanotował po wyjściu z przedstawienia Anieli w 1845 roku: „Żadnej komplikacji wypadków, żadnej intrygi. Uważamy ten przedmiot za nadto ograniczony, za nadto ciasny na wymiary tragedii. [...] Charakterom tragedii zarzucamy jednotonność" ${ }^{37}$. W tak opracowanej formie dramatycznej zaznacza się zaiste ręka autora Klary. Nieco dalej recenzent wyrokował, „[...] że główną wadą Anieli jest to, że forma liryczna zanadto w niej przebija" ${ }^{38}$.

34 Zob. M. Szyjkowski, Schiller w Polsce. Studium historyczno-porównawcze, Kraków 1915, s. 252-271.

Zob. K. Kurek, Polski Hamlet. Z historii idei i wyobraźni narodowej, Poznań 1999, s. 99.

36 J. Słowacki, dz. cyt., s. 282-283.

37 Wielki Teatr. „Aniela. Trajedia w pięciu aktach oryginalnie wierszem nierymowym”, przez Józefa Korzeniowskiego napisana, „Gazeta Warszawska” 1845, nr 318, s. 2.

38 Tamże, s. 3 . 
Bezpośrednio w stronę Klary skierował uwagę Chmielowski, który Aniele potraktował jak nieudolnie rozbudowaną wersję pierwszego dramatu, dostrzegłszy podobieństwo w rysunku „charakterów”, przeniesione nie całkiem chyba świadomie - poprzez ustawienie w pary kreacji zdublowanych - na poziom zestawu dramatycznych ról przypisanych poszczególnym postaciom ${ }^{39}$. Schematycznie można by tę parzystą charakterystykę postaci z rozprawy Chmielowskiego przedstawić tak:

\begin{tabular}{|c|c|c|}
\hline POSTAĆ z KLARY & POSTać Z ANIELI & UZUPEENIENIE \\
\hline Albert & Herman & - \\
\hline Klara & Aniela & $\begin{array}{l}\text { „tylko ponieważ nie po- } \\
\text { trzebuje zachowywać życia } \\
\text { swego dla syna, zażywa } \\
\text { truciznę, którą Klara jedynie } \\
\text { przy sobie nosiła" }\end{array}$ \\
\hline Henryk (syn Klary) & Zofia (siostra Anieli) & - \\
\hline Hrabia & Gustaw hr. Przeworski & $\begin{array}{l}\text { „tylko że ów brak decyzji, } \\
\text { trwający przez lat sześć, } \\
\text { u Gustawa zamienia się } \\
\text { w chroniczną chorobę } \\
\text { woli, nawianą zapewne } \\
\text { od Szekspirowskiego } \\
\text { Hamleta" }\end{array}$ \\
\hline- & $\begin{array}{l}\text { Helena, } \\
\text { wdowa po kasztelanie } \\
\text { Bełzkim }\end{array}$ & $\begin{array}{l}\text { „jest nową figurą, mającą } \\
\text { więcej śmiałości, energii } \\
\text { i stanowczości od Anieli, } \\
\text { zapowiada ona te silnie } \\
\text { rysowane charaktery } \\
\text { kobiece” [z późniejszych } \\
\text { dramatów Korzeniow- } \\
\text { skiego] }\end{array}$ \\
\hline- & Wilhelm Stański & $\begin{array}{l}\text { „wytrwale, ale cicho } \\
\text { i pokornie kochający } \\
\text { Anielę" }\end{array}$ \\
\hline- & Ludwik Stężyc & „powiernik Gustawa” \\
\hline- & $\begin{array}{l}\text { Grabarze występujący } \\
\text { pod koniec sztuki }\end{array}$ & „naśladowani z Szekspira” \\
\hline
\end{tabular}

W uwolnionym od Schillerowskich i Szekspirowskich konotacji zestawieniu dwóch dramatów „lirycznych” i ,jednotonnych” gęstsze zaludnienie późniejszej Anieli wygląda na dyktowane potrzebą wypełnienia czymś pięciu aktów przy słabo rozkręconej akcji. Zabieg ten sam w sobie nie przydał jesz-

Zob. P. Chmielowski, dz. cyt., s. 31. 
cze utworowi dramatyzmu, ale wyraźnie zaczął rozsadzać liryczność, niszczyć spójność syntezy wyrazu autorskiej podmiotowości.

Toteż przy uznaniu wartości Klary jako eksperymentu formalnego Aniela wygląda na twór przejściowy, bardziej objaw rozkładu struktury uformowanej w pierwszym dramacie niż zwiastun kierunku nowego.

Dynamizujące akcję przełamanie „jednotonności charakterów” Chmielowski zaobserwował dopiero w dramatach powstałych po Mnichu. Przyznawał co prawda, że już i w Mnichu samym Korzeniowski przedstawił „człowieka występnego, nie jak w Klarze i Anieli” ${ }^{\circ}$, jednak „[...] i ten występny, ukarany strasznym upadkiem, oczyszczony cierpieniem i zwycięstwem nad sobą, doznaje błogosławienia" ${ }^{41}$. Co więcej, występność głównego bohatera należy do preakcji i nawet tytuł dość prowokacyjnie definiuje postać Bolesława Śmiałego w obrębie akcji dramatycznej, osadzonej na legendarnym motywie pokuty wyklętego króla w klasztorze w Osjaku, w Karyntii.

Nie tylko historia (zarówno ta rzetelna, naukowa, jak i ta popularna, karmiąca wyobraźnię - na ówczesną skalę - masową), ale i praktyka pisarsko-inscenizacyjna podsuwały inne, obficiej wyposażone w dramatotwórczy potencjał zdarzenia z królewskiej biografii. Bolesław Wtóry Franciszka Wężyka, dramat $\mathrm{z} 1815$ roku, w akcji uruchomionej przybyciem króla $\mathrm{z}$ Kijowa i jego rozprawą $z$ dezerterami rozwijał wątek odsunięcia królowej Wisławy na rzecz kochanki, Krystyny (w wersji Wężyka uprowadzonej z domu męża, Mścisława, i przetrzymywanej na Wawelu wbrew własnej woli), poprzez kolejne konfliktowe starcia bohatera tytułowego z biskupem Stanisławem i z samą Krystyną, formując tragedię namiętności, kojarzoną w krytycznych komentarzach z typem racine'owskim ${ }^{42}$. Antoni Hoffmann w Bolesławie Śmiałym, tragedii pochodzącej również z 1815 roku, wokół spisku zawiązanego przeciwko królowi już po zabiciu przezeń biskupa osnuł tragedię intrygi, obejmującej demaskację buntowników przez Bolesława i jego dumną a zgubną dla kraju abdykację ${ }^{43}$.

Pierwszą zaś romantyczną wersję dramatu „bolesławowskiego”, podporządkowaną zasadom romantycznego historyzmu oraz schellingiańskiej koncepcji

40 P. Chmielowski, dz. cyt., s. 34.

41 Tamże.

42 Zob. M. Szyjkowski, Dzieje nowożytnej tragedii polskiej. Typ pseudoklasyczny, Kraków 1920, s. 295-301.

43 W kategoriach świadomej zemsty interpretuje decyzję króla w tragedii Wężyka Dobrochna Ratajczakowa (Wstęp, w: Polska tragedia neoklasycystyczna, oprac. D. Ratajczakowa, Wrocław 1988, s. CLIII). 
tragizmu walki „wolnej woli” jednostki z historyczną „koniecznością”, zaprojektował Maurycy Mochnacki, kreśląc rozległą panoramę dziejową, obejmującą wyprawę kijowską, proces i śmierć biskupa oraz pokutę króla - ujęte w perspektywie dziejowego mechanizmu rywalizacji dwóch systemów władzy: świeckiej i duchownej. I to wszystko - w miażdżącej recenzji Mnicha Korzeniowskiego, ogłoszonej w „Kurierze Polskim” z 13 lipca 1830 roku. Data jest o tyle ważna, że lokalizuje owo wystąpienie w określonym programie krytyka, który w miarę narastania przedpowstańczej gorączki przewartościowywał kryteria oceny dzieł literackich, porzucając estetykę na rzecz etyki i wpisując rewolucję artystyczną w proces dojrzewania rewolucji politycznej - poprzez negację poezji w jego własnej typologii zwanej „subiektową”, wyrażającej egzystencjalne dylematy romantycznego indywidualizmu, oddalonej od epickich z natury tematów poezji „obiektowej”, skupionej na kwestiach istotnych z punktu widzenia zbiorowości ${ }^{44}$. W tym kontekście nieżyczliwa ocena $\mathrm{Mni}$ cha świadczyłaby akurat za jego charakterem lirycznym - subiektywnym, podmiotowym. Lepiej by też ta klasyfikacja odpowiadała intencjom autora, który wyborem ostatniego okresu życia historycznego władcy i podkreśleniem celowości tego wyboru w tytule wyraźnie dystansował się wobec opracowania tematu w tragediach narodowych, w momencie wydania dramatu Korzeniowskiego znanych czytającej publiczności i ze sceny, i z lektury - tragedię Hoffmanna, wystawioną w Warszawie w 1815 roku, wydano w 1829, tragedia Wężyka, zaprezentowana na warszawskiej scenie w 1816, ogłoszona została drukiem już w 1822 roku $^{45}$. Mochnacki taktycznie ten kontekst przemilczał, ale zestaw przedlistopadowych dramatów „bolesławowskich” mógł rodzić recenzenckie dylematy zbliżone do tych, które później stały się udziałem krytyków porównujących dramatyczne opracowania historii Marii Stuart i ganiących Słowackiego za brak w dramacie „rozwiązania” obejmującego ostatnie chwile życia zdetronizowanej królowej, a Schillera za wypełnienie samym „rozwiązaniem" całej tragedii ${ }^{46}$ (która, nawiasem mówiąc, dostarczyła Korzeniowskiemu motta do jego utworu) - oni także, podobnie jak ideologicznie już „zapro-

44 Zob. Z. Przychodniak, Wstep, w: M. Mochnacki, Pisma krytyczne i polityczne, wyb. i oprac. J. Kubiak, E. Nowicka, Z. Przychodniak, t. 1, Kraków 1996, s. 24.

45 Dokładne zestawienie dat premier i wydań podaje Ratajczakowa (dz. cyt., s. LXXXIX-CX).

46 „Ostatnia scena dramatu, dolatujące z dala krzyki ludu i końcowe «Uciekajmy!» Botwela, wyglądają na zakończenie przedostatniego aktu, po którym dopiero nastąpi właściwe rozwiązanie, bunt przeciw Marii Stuart, usiłowania obrony, wreszcie ucieczka jej do Anglii i uwięzienie [...]. Marii Stuart Schillera zarzucano, i nie bez słuszności, że jest znowu samym tylko rozwiązaniem. [...] Wszelako, mniejsze to złe u Schillera, że jego dramat jest samym rozwiązaniem, jak u Słowackiego, że nie ma rozwiązania” (S. Tarnowski, Profesora Małeckiego „Juliusz Słowacki”, „Przegląd Polski” 1867, z. 4, s. 3). 
gramowany” Mochnacki, za dobrze wiedzieli, jak ten dramat "powinien” być napisany. W tę samą zresztą pułapkę wpadł również obrońca Mnicha z 1830 roku, który, skupiwszy się właściwie na arbitralności sądu „Kuriera Polskiego” (odpowiadał gazecie, gdyż recenzja Mochnackiego była w niej ogłoszona anonimowo), niechcący poparł ostatecznie projekt realizacji tematu z bardziej „obiektowym” rozmachem, uznając Mnicha „[... [ za część ostatnią pięknej trylogii, której tylko uzupełnienia od Korzeniowskiego domagać się możemy" ${ }^{47}$.

Po upływie niemal stu lat Mnich ponownie uruchomił myślenie w kategoriach trylogii, za sprawą porównania $\mathrm{z}$ utworem aktywującym je nawet podwójnie, jako że Edyp w Kolonos Sofoklesa - z którym, na przekór ugruntowanym już przekonaniom o byronowsko-szekspirowskim rodowodzie dramatu Korzeniowskiego, porównał go Ignacy Chrzanowski ${ }^{48}$ - po pierwsze powstał w kulturze tragediowych trylogii, po drugie zaś nawiązywał czytelnie do wątków i motywów z dwóch wcześniejszych tragedii Sofoklesa z dziejów rodu Labdakidów - Antygony i Króla Edypa, fabularnie okalających akcję tej późnej sztuki, obejmującą zdarzenia zaszłe po wygnaniu ojcobójcy i kazirodcy z Teb, a poprzedzające ostateczną rozgrywkę jego synów w walce o królewską schedę.

Co ciekawe, Chrzanowski też wyszedł od krytyki stanowiska Mochnackiego, któremu wypomniał grzech tendencyjnej oceny, przekonując, że nie musiało wcale być intencją Korzeniowskiego stworzenie w Mnichu dramatycznej panoramy historycznej o epickich parantelach i z historiozoficznym podkładem. Za dowód posłużył Kurs poezji i zawarta w nim typologia tragedii, oferująca możliwość wyboru jednej z czterech odmian, wyróżnianych w oparciu o trzy zasadnicze kryteria. Przy użyciu cytatów z Kursu poezji ${ }^{49}$, zachowując autorską kolejność i hierarchię kryteriów, typologię Korzeniowskiego można w skrócie przedstawić tak:

\begin{tabular}{|c|l|l|l|l|}
\hline & $\begin{array}{c}\text { TRAGEDIA } \\
\text { HEROICZNA }\end{array}$ & \multicolumn{1}{|c|}{$\begin{array}{c}\text { TRAGEDIA } \\
\text { ROMANTYCZNA }\end{array}$} & $\begin{array}{c}\text { TRAGEDIA } \\
\text { HISTORYCZNA } \\
\text { WLAŚCIWA }\end{array}$ & $\begin{array}{c}\text { TRAGEDIA } \\
\text { HISTORYCZNA } \\
\text { PRYWATNA }\end{array}$ \\
\hline 1 & $\begin{array}{l}\text { temat „Z czasów } \\
\text { heroicznych } \\
\text { starożytności” }\end{array}$ & $\begin{array}{l}\text { temat „Z czasów } \\
\text { rycerstwa } \\
\text { chrześcijańskiego” }\end{array}$ & $\begin{array}{l}\text { konflikt między } \\
\text { bohaterami } \\
\text { dotyczy spraw } \\
\text { publicznych }\end{array}$ & $\begin{array}{l}\text { konflikt między } \\
\text { bohaterami } \\
\text { dotyczy spraw } \\
\text { prywatnych }\end{array}$ \\
\hline
\end{tabular}

47 M.M. [M. Mochnacki], [O recenzji „Mnicha”...], „Gazeta Polska” 1830, nr 219, s. 1.

48 Zob. I. Chrzanowski, Źródła klasyczne dwu utworów romantycznych („Grażyny” Mickiewicza i „Mnicha” Korzeniowskiego), Warszawa 1916, s. 67-93.

49 J. Korzeniowski, Kurs poezji, Warszawa 1829, s. 220-222. 


\begin{tabular}{|c|c|c|c|}
\hline 2 & \multicolumn{2}{|c|}{ „idealność” } & \multirow[b]{2}{*}{$\begin{array}{l}\text { „poetyczne naśladowanie } \\
\text { rzeczywistości”, } \\
\text { „pozór prawdy historycznej” }\end{array}$} \\
\hline & $\begin{array}{l}\text { „W pomysłach } \\
\text { poety i w for- } \\
\text { mach, pod } \\
\text { którymi osoby } \\
\text { swoje wystawia” }\end{array}$ & $\begin{array}{l}\text { „w ludziach, którzy } \\
\text { działają, i w dąże- } \\
\text { niu ich myśli do } \\
\text { przebywania } \\
\text { w świecie rojeń” }\end{array}$ & \\
\hline 3 & „cudowność" & & $\begin{array}{l}\text { „ludzie zostawieni własnym swoim } \\
\text { siłom” }\end{array}$ \\
\hline
\end{tabular}

Chrzanowski wnioskował, że Mnich, skoro czasem akcji obejmuje tylko prywatną pokutę króla, nie jest „tragedią historyczną właściwą”, a ponieważ wprowadza element cudowny, więc nie może być nawet „tragedią historyczną prywatną” - musi być tedy „tragedią romantyczną”. Argumentem rozstrzygającym, aczkolwiek przez badacza nieprzywołanym wprost, pozostawał ten, który ograniczał możliwość wyboru do trzech spośród czterech nazwanych wariantów, a więc historycznoliteracki charakter pierwszej opozycji. Z dalszych wywodów Korzeniowskiego w Kursie poezji wynika, że „tragedia heroiczna” w epoce nowożytnej nie jest możliwa nawet przy temacie „z czasów heroicznych starożytności”, czego dowodzi kształt klasycystycznej tragedii francuskiej, „[...] w której przeznaczenie przestało być najgłówniejszą sprężyną, w której ludzie własnym siłom zostawieni zostali, która z dramatu religijnego na historyczne się zamieniła” ${ }^{50}$. Zgodne to z istotą starożytnej „idealności", ale nie istotą zdefiniowaną w tragediowej typologii, lecz tą z rozdziału poświęconego tragedii greckiej, gdzie Korzeniowski słusznie przypisał jej motywację religijną ${ }^{51}$. Wiadomo, że w dramacie greckim bogowie nie byli zjawiskiem cudownym, lecz naturalnym, tak jak oczywiste były dla ówczesnych odbiorców ich koneksje z mitycznymi herosami. Jednakowoż w typologicznym podziale Korzeniowskiego „idealność” odnajdywana „[...] w pomysłach poety i w formach, pod którymi osoby swoje wystawia”, zatracała swój wymiar historyczny i stawała się cechą poetyki dramatu nazwanego „tragedią hero-

50 Tamże, s. [241].

51 „W mitologii złożonej z tradycji i wspomnień miejscowych znajdowało się źródło religii i historii Greków. Heroiczne te bajki, odsunione przez czas, okazywały się ucywilizowanym Ateńczykom w świetle wątpliwym, lecz cudownym. Były one najupodobańszym przedmiotem tragików greckich; ludzie więc, którzy w nich działali, których początek wyprowadzano od bogów, musieli być obdarzeni siłą i darami nadzwyczajnymi. Dlatego to wystawieni byli przez poetów zupełnie idealnie. Nie są to osoby moralnie doskonałe; mają owszem swoje słabości, wady i występki; lecz w ogóle ich uczuć, myśli, sił i kształtów jest coś wyższego nad rzeczywistość” (tamże, s. [232]). 
iczną”. Jej przeciwstawienie idealności „romantycznej”, realizowanej „w ludziach, którzy działają, i w dążeniu ich myśli do przebywania w świecie rojeń”, można by rozwijać w kierunku chrześcijańskiego rozbicia pierwotnego uniwersum na świat realny i duchowy, a dalej w stronę romantycznego głodu mitycznej syntezy, dla której stworzenia „sam poeta musi mit cały ukształcić” - by przywołać tylko przykładowo uwagę Zygmunta Krasińskiego, poczynioną przy okazji krytycznego rozbioru Balladyny ${ }^{52}$. Oczywiście wątpliwe, by pisząc w młodym wieku swój Kurs poezji, Korzeniowski miał świadomość wskazywania drogi do realizacji tak wybujałych ambicji romantyzmu, jednak sama zasada ustanawiania „idealności” „w pomysłach poety i w formach”, w swej istocie uniwersalna i ponadczasowa, odpowiada wszak metodzie liryzowania dramatu romantycznego poprzez subiektywizację świata przedstawionego. Hipotetycznie zatem dramat nowożytny, uruchamiający w akcji siły nadprzyrodzone, mógł - nawet zgodnie z przedstawioną w Kursie poezji filozofią tragedii - realizować poprzez liryzację wariant „heroiczny”, który w intencji Korzeniowskiego sygnalizował swą nazwą nie jakość czynów postaci (te w teatrze greckim bywały mało bohaterskie), ale właśnie naturalność powiązań postaci i ich codzienności z jakąś boską transcendencją.

Proponowane tu przesunięcie akcentu w charakterystyce odmiany gatunkowej z uwarunkowań historycznych na poetykę immanentną nie zmienia klasyfikacji Mnicha, tylko inaczej ją uzasadnia. Ściślej mówiąc, nie rozstrzyga o usytuowaniu wśród kategorii romantyzmu i historyzmu, lecz oddala ów dramat od subiektywnej idealizacji świata przedstawionego, obserwowanej przez Korzeniowskiego w tragedii antycznej.

Dodać można, że akurat Edyp w Kolonos chętniej niż inne tragedie bywał kojarzony z formą liryczną - Kazimierz Kaszewski na przykład w 1853 roku nazwał go „udramatyzowaną sielanką":

Sam Edyp w tym utworze jest główną postacią; cały charakter tragedii jest jego charakterem. Powaga, religijność, wszystko co cechuje starca, zlało się tu, żeby całej sztuce nadać jakąś barwę starości. Nie ma w niej tej dramatyczności, jaką zaleca się Edyp król, ani tego życia, jakie widzieliśmy w Antygonie; ale można by ją bezpiecznie nazwać udramatyzowaną sielanką. ${ }^{53}$

W tym akurat punkcie spostrzeżenia dziewiętnastowiecznego filologa, tłumacza i poety nie odbiegały znacząco od komentarzy formułowanych współcześnie, w których rozwlekłość lirycznego zakończenia tej późnej sztuki Sofo-

52 Z. Krasiński, Kilka słów o Juliuszu Słowackim w: tegoż, Dzieła literackie, oprac. P. Hertz, t. 3, Warszawa 1973, s. 260.

53 K. Kaszewski, Przedmowa, w: Edyp w Kolonie. Tragedia Sofoklesa, przeł. K. Kaszewski, „Biblioteka Warszawska” 1853, t. 4, s. 100. 
klesa usprawiedliwia się przeniesieniem tragizmu z obszaru akcji (tam lokalizowanego w Królu Edypie) do sfery namiętności ${ }^{4}$ oraz przypomina się, „[...] że jedność utworu jest stworzona przez bohatera tytułowego, występującego we wszystkich scenach sztuki jako postać jednocząca ich akcję oraz jako temat organizujący świat poetycki w pieśniach chóralnych" 55 .

Prawdę mówiąc, z tym wszystkim Edypowi w Kolonos bliżej do lirycznego dramatu romantycznego - tym razem $\mathrm{w}$ wariancie skupionym na ekspresji ja bohatera - niż Mnichowi Korzeniowskiego. Wymowny wydaje się fakt, że podobieństwa między nimi, dość zresztą powierzchowne, Chrzanowski odnalazł tylko w budowie akcji. Ich prezentację zaś poprzedził w cytowanej rozprawie długi katalog różnic, odnotowanych w obszarach kompozycji, wymowy ideowej, formuły tragizmu i konstrukcji „charakterów”. W obszarze pogranicza wspólnego tym przestrzeniom tkwi różnica najwyrazistsza: tragiczne namiętności starego Edypa nadają ton tragedii Sofoklesa dzięki swoim powiązaniom z wyrokami bogów obecnych niejako obiektywnie w jednolitym światopoglądzie wszystkich postaci. Paradoksalnie, coś z tego było jeszcze w Klarze. W Mnichu zaś - wyraźniej niż w Anieli - zaznacza się już rozłam, i to biegnący wzdłuż kilku osi, z których najważniejsza oddziela świat zmysłowy od duchowego.

Zjawisko to pogłębia się w kolejnych dramatach, którym nie przypisywano już lirycznych kształtów gatunkowych.

Bitwa nad Mozgawa $q^{56}$ uformowana została ściśle według sporządzonego w Kursie poezji opisu „tragedii historycznej” z domieszką politycznej aluzji, podsuwającej w ramach historyzmu maski rozbicie dzielnicowe jako figurę rozbiorów ${ }^{57}$. W tej optyce międzypokoleniowy konflikt hamletyzującego Bolesława z Mieszkiem Starym (Mieczysławem), skupionym na wojnie o dzielnicę krakowską, odsyła do historycznych doświadczeń generacji polskich roman-

54 Zob. H.D.F. Kitto, Tragedia grecka. Studium literackie, przeł. J. Margański, Bydgoszcz 1997, s. 350-353.

55 R.R. Chodkowski, Wstęp (do Edypa w Kolonos), w: Sofokles, Tragedie, przeł., wstęp i przyp. R.R. Chodkowski, t. 1, Lublin 2009, s. 405.

56 Rkps Ossol. sygn. 2872/II; odpis w zbiorach Biblioteki Narodowej, sygn. 6o66; dostęp zawdzięczam uprzejmości prof. dra hab. Krzysztofa Kurka z Katedry Dramatu, Teatru i Widowisk Uniwersytetu Adama Mickiewicza w Poznaniu.

57 Zob. D. Ratajczakowa, Polski Hamlet czyli „Bitwa nad Mozgawą” w: tejże, W krysztale i w płomieniu. Studia i szkice o dramacie i teatrze, wyb. i oprac. B. Koncewicz, t. 2, Wroclaw 2006, s. 63-64. 


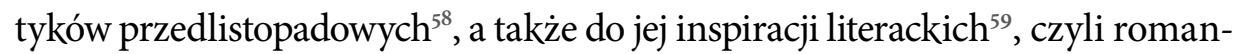
tycznych fabuł napiętnowanych nieobecnością postaci ojca, poświadczającą często analogiczny brak w biografiach ich autorów ${ }^{60}$.

Jednego wszakże romantycznego ojca literackiego, też oszczędnie scharakteryzowanego, ale w akcji macierzystego utworu obecnego stale poprzez skutki swych postanowień (dla rozwoju akcji decydujące) Korzeniowski wystawił na scenę. Dosłownie i w przenośni. Dosłownie w 1846 roku. Teatralna premiera Dymitra i Marii wywołała naturalną w tej sytuacji reakcję krytyczną opartą na konfrontacji dramatu z jego epickim pierwowzorem, czyli Maria Malczewskiego, która wówczas miała już status kanonicznego arcydzieła polskiego romantyzmu, mocno podkreślony w pierwszych zdaniach recenzji dramatu opublikowanej w „Gazecie Warszawskiej”. W tej samej recenzji jednak przypomniano też dzieje recepcji Marii, do czasu ogłoszenia w 1830 roku słynnej rozprawy Mochnackiego praktycznie nieobecnej w refleksji krytycznej i nieznajdującej nawiązań w literaturze. W tych okolicznościach decyzja o przygotowaniu scenicznej adaptacji poematu Malczewskiego w sezonie teatralnym 1827/1828 świadczyłaby raczej na korzyść Korzeniowskiego. Czas powstania Dymitra i Marii sytuuje zarazem ten dramat bardzo blisko Bitwy nad Mozgawa. Mogła wręcz na jego kształcie zaważyć wiadomość o poprzednim utworze, „że cenzor ówczesny Szydłowski [...] osądził go jako przeciwny rządowi, religii i moralności" ${ }^{\prime 1}$.

Zdaje się, że w nowym dramacie, którego epicki pierwowzór też chyba w jakimś stopniu oddziaływał na poprzedni, autor postanowił wykorzystać niektóre chwyty sprawdzone już w odrzuconej przez komitet cenzury tragedii z czasów rozbicia dzielnicowego. Najbardziej z nich uderzającym jest wprowadzenie postaci niemającej odpowiednika w powieści Malczewskiego. Stefan, „faworyt wojewody”, dawny konkurent do ręki Marii, odtrącony na rzecz Dymitra (dramatycznego Wacława), podsyca nienawiść Wojewody do syna, podobnie jak to czyni z Mieczysławem podstępny Wszebor w Bitwie nad Mozgawa. Przyznanie tej samej funkcji postaci o identycznej w obu dramatach pozycji w układzie relacji między bohaterami skutkuje zbliżeniem mechanizmów rozwoju akcji, którą tu i tam napędzają bardzo podobnie zbudowane

58 Zob. tamże.

59 Zob. K. Kurek, Polski Hamlet..., s. 110-111.

60 Zob. M. Piwińska, Złe wychowanie. Fragmenty romantycznej biografii, Warszawa 1981, s. 281-282.

61 Fragment listu Korzeniowskiego do Estreichera z 10 lipca 1858 roku, ogłoszonego przez Mariana Gawalewicza w „Bibliotece Warszawskiej” z 1897 roku (t. 1, s. 507), cytuje Stefan Kawyn (Józef Korzeniowski. Studia i szkice, Łódź 1978, s. 25). 
sceny węzłowe. W jednym i w drugim dramacie uruchamia działanie rozwścieczonego ojca jego rozmowa $\mathrm{z}$ judzącym faworytem o postępowaniu syna. Akt drugi tu i tam otwiera narada przebiegłych dworaków - Wszebora z Borzywojem i Stefana z Dworzaninem - odkrywająca zamiary sterowania emocjami możnowładcy dla odniesienia osobistych korzyści, w obu wypadkach przerwana wejściem pana zamku, które od razu umożliwia pokaz zapowiedzianej strategii. W aktach trzecich paralelne są rozmowy zakochanych par, poświęcone okolicznościom zmuszającym do rozstania z powodu obowiązkowego udziału młodych rycerzy w działaniach wojennych, z tym że w Bitwie nad Mozgawą chodzi o rzeczywistą wojnę domową, a w Dymitrze i Marii - o wojnę z Tatarami, zmyśloną przez przybocznych Wojewody w celu wywabienia z domu Dymitra, toteż naradom wojennym Mieczysława i jego stronników z drugiej połowy trzeciego aktu odpowiada bezcelowe snucie się Dymitra z żołnierzami po lesie w poszukiwaniu oddziałów tatarskich w pierwszej scenie aktu czwartego, zakończone odkryciem kłamstwa Wojewody. W pierwszych scenach czwartego aktu Bitwy nad Mozgawą ludzie Mieczysława zamykają w klasztorze porwaną Hannę (ukochaną Bolesława) i na tym samym odcinku Dymitra i Marii Wojewoda zjawia się w domku zmarłej żony, gdzie z woli męża kryła się przed nim synowa, aby Stefanowi zlecić jej uprowadzenie, choć wszystkie rozmowy toczone w tych scenach przenika myśl o śmierci Marii i ona ostatecznie prowokuje odrzuconego zalotnika do zabójstwa. I jak w przeróbce poematu Malczewskiego Dymitr relacjonuje swe straszne odkrycie - zburzenie domu Marii i zaoranie miejsca, w którym stał, tak w tragedii z dziejów średniowiecznych Bolesław odbiera od opiekuna Hanny wieści o jej porwaniu i zburzeniu zamku. W Bitwie nad Mozgawa następuje po tym odkryciu słynna „hamletowska” scena z bajką Bolesława „o królu i jego synu”, opowiadaną podczas narady wojennej u Mieczysława i pełniącą funkcję „pułapki na myszy”, która sprowadzi decydujący zwrot akcji. W Dymitrze i Marii - już tylko zabicie Stefana przez Dymitra i samobójcza śmierć owdowiałego syna, spełniającego toast trucizną na oczach ojca.

I jak ów mocny scenicznie akord samobójstwa Dymitra zastąpił w dramacie otwarte zakończenie powieści Malczewskiego, tak tajemniczość i aktywność Wojewody wymieniono na pasywne raczej gadulstwo, a wieloznaczne Pacholę na jednoznaczną Cygankę, będącą wspomnieniem jakiegoś grzechu z czasów młodości Wojewody, wszelako nie o charakterze romansowym (postać to w sumie bliższa biografią widmu Sowy z II części Dziadów, choć funkcją odpowiada Kseni z Zamku kaniowskiego). Przede wszystkim zaś egzystencjalną głębię przeżyć zastąpił skonkretyzowany strach i doraźna udręka, gdyż obsesja śmierci w światopoglądzie Marii tłumaczy się u Korzeniowskiego 
stałą obawą przed gniewem Wojewody i ciągłymi wyrzutami czynionymi jej przez Ojca. Historyczne i metafizyczne zło z poematu Malczewskiego znalazło uproszczony widzialny odpowiednik w osobie intryganta Stefana. Znikła egzystencjalna tajemnica, zamilkła polifonia światopoglądów, wyrażająca tragiczne doświadczenie losu, ale za to akcji starczyło na pięć aktów i nie padało już oskarżenie o formalny liryzm. Zarzuty, które stawiano Dymitrowi i Marii - między innymi powolnego działania, niezręcznego ugrupowania wypadków, rozwlekłości dialogów etc. ${ }^{62}$ - określały już bezsprzecznie dramat, tyle że... „źle skrojony”, co jednak nie znaczy, że źle napisany.

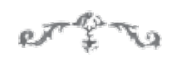

A B S T R A C T

Józef Korzeniowski's Youthful Experiments with the Subjectivity of Dramatic Form

The status of Józef Korzeniowski's early dramas oscillates around the historical and literary syntheses of his works (the first of which date back to the 1840 s) between a modest position of a technical "rehearsal" and a high rank of an innovative dramatic form. Paradoxically, while the old "defensive" reviews do not sound credible today, the "accusatory" statements - when deprived of their judgmental conclusions - offer inspiring suggestions. They are supported by a superior category of lyricism. Yet, it is not the lyricism that institutes the dramatic genre of the lyrical stage (asthe first critics sympathetic to the poet desired), but the lyricism that is expressed in the subjectivity of statements (with the voices written out, yet conflict-ridden by the consequences of actual past actions, not in the sphere of current experiences), in the elegiac mood of personal reflections, and finally in such projection of reception that was expected even by the normative poetics of classicism for lyrical forms, and even for their variations most toned down in meaning and most personal in content. From this perspective, the series of Korzeniowski's early dramas show evidence of his gradual resignation from a brave experiment for the sake of an awkwardly constructed form of drama following the "regulations."

KE Y WORDS

Józef Korzeniowski, lyric poetry, drama, Romanticism 